\begin{tabular}{llllllllllll}
$\mathrm{S}$ & $\mathrm{P}$ & $\mathrm{R}$ & $\mathrm{A}$ & $\mathrm{W}$ & $\mathrm{O}$ & $\mathrm{Z}$ & $\mathrm{D}$ & $\mathrm{A}$ & $\mathrm{N}$ & $\mathrm{I}$ & $\mathrm{A}$ \\
\hline
\end{tabular}

Konferencja naukowa pt Ochrona danych osobowych w Kościele, Warszawa, 25 lutego 2016 r.

W dniu 25 lutego 2016 r. w Sali Rady Wydziału Prawa i Administracji Uniwersytetu Kardynała Stefana Wyszyńskiego w Warszawie odbyła się konferencja naukowa pt Ochrona danych osobowych $w$ Kościele. Konferencja została zorganizowana przez Generalnego Inspektora Ochrony Danych Osobowych, Uniwersytet Kardynała Stefana Wyszyńskiego w Warszawie, Uniwersytet Opolski i Uniwersytet Szczeciński.

Program konferencji składał się z czterech sesji. Uroczystego jej otwarcia dokonali ks. prof. Stanisław Dziekoński (rektor UKSW) oraz dr Edyta Bielak-Jomaa (GIODO). Witając wszystkich uczestników, ukazali problematykę zorganizowanej konferencji naukowej i jej aktualność w związku $\mathrm{z}$ aktualnymi problemami wynikającymi z ochrony danych osobowych w działalności kościołów i innych związków wyznaniowych.

Sesja pierwsza została zatytułowana Przetwarzanie $i$ ochrona danych osobowych $w$ Kościele. Przewodniczył jej prof. Andrzej Rzepliński prezes Trybunału Konstytucyjnego. Pierwszy referat pt. Jawność $i$ jej granice $w$ Kościele wygłosił ks. prof. Stanisław Dziekoński (UKSW). Prelegent na początku swojego wystąpienia zdefiniował pojęcia Kościoła, związku wyznaniowego i kościelnych osób prawnych. Następnie omówił swobodę kształtowania struktury wewnętrznej osób prawnych Kościoła, by wreszcie dokonać prawnej analizy zagadnienia ochrony danych osobowych i ich przetwarzania przez kościoły i związki wyznaniowe o uregulowanej sytuacji prawnej.

Poprzez nagranie video uczestnicy Konferencji mieli możliwość zapoznania się z treścią kolejnego wystąpienia nt. Ochrona danych osobowych w Kościele z perspektywy europejskiej, które wygłosił Giovanni 
Buttarelli (Europejski Inspektor Ochrony Danych Osobowych). W swoim słowie zwrócił uwagę na uwzględnianie w ochronie danych osobowych w kościołach i innych związkach wyznaniowych nowych technologii oraz stosowanie dwóch zasad: rozliczalności i przejrzystości. Ponadto wspomniał także o zakończonych pracach nad projektem rozporządzenia Parlamentu Europejskiego i Rady w sprawie ochrony osób fizycznych w związku z przetwarzaniem danych osobowych i swobodnym przepływem takich danych (ogólnie rozporządzenie o ochronie danych, Bruksela, dnia 25 stycznia 2012 r., COM (2012) 11 final).

Przetwarzanie danych osobowych jako przykład realizacji konstytucyjnej zasady autonomii Kościoła, to temat referatu prof. Pawła Sobczyka (UO). Swój referat autor rozpoczął od omówienia problemów związanych z interpretacją zasady autonomii i niezależności kościołów i innych związków wyznaniowych (art. 25 ust. 3 Konstytucji z 1997 r.). Kolejno dokonał próby omówienia tej zasady wobec kwestii przetwarzania danych osobowych przez kościoły i związki wyznaniowe posiłkując się aktualnym orzecznictwem Naczelnego Sądu Administracyjnego.

Ostatnim referatem tej sesji było wystąpienie dr. Michała Poniatowskiego (UKSW) pt. Przetwarzanie danych osobowych $w$ kościelnych organizacjach pożytku publicznego. Prelegent dokonał wnikliwej analizy przetwarzania danych osobowych w związku z działalnością charytatywno-opiekuńczą Kościoła, wykazując przy tym że ta działalności jest fundamentem działalności Kościoła.

Drugiej sesji zatytułowanej Ochrona danych osobowych w świetle prawa publicznego przewodniczyła prof. Irena Lipowicz (UKSW). Jako pierwszy w tej sesji wystąpił dyr. Piotr Drobek (Biuro GIODO, UKSW) z referatem zatytułowanym Projekt rozporządzenia Parlamentu Europejskiego i Rady o ochronie danych osobowych a przetwarzanie danych osobowych w Kościele. Prelegent ukazał wpierw podstawy prawne ochrony danych osobowych w Unii Europejskiej, uwzględniając przy tym wyroki Europejskiego Trybunału Praw Człowieka. W dalszej kolejności omówił artykuły rozporządzenia dotyczące ochrony danych osobowych w kościołach i związkach wyznaniowych (art. 9 ust. 1, art. 85 i art. 91 rozporządzenia).

Ks. prof. Piotr Mazurkiewicz (UKSW) w referacie pt. Geneza regulacji europejskiej ochrony danych osobowych w Kościele i potrzeba badań prawnoporównawczych, poszukał odpowiedzi na pytanie: dlaczego rozporządzenie unijne, a nie dyrektywa. W swoim wystąpieniu zwrócił uwagę na religijną różnorodność w Europie, która winna być uwzględniana w przepi- 
sach unijnych (art. 4 Traktatu o funkcjonowaniu UE). Unia Europejska powinna przetwarzać dane osobowe ze względu na żywotny interes osoby, której dane dotyczą. Przywołując przykładowe unormowania państw należących do Unii Europejskiej dokonał analizy na czym polega prawo do prywatności i prawo do wolności religijnej.

Kolejny referat w tej sesji wygłosił prof. Ansgar Hense (Bonn, Instytut für Staatskirchenrecht der Diözesen Deutschlands). Swoje wystąpienie zatytułował Ochrona danych osobowych w Kościele w prawie niemieckim. Referat dotyczył analizy aktów prawnych i skupiony był wokół zagadnień: konstytucyjo-prawne i podstawowe współrzędne odnośnie do danych osobowych, podstawowe struktury dotyczące rozporządzenia o kościelnej ochronie danych osobowych oraz aktualne informacje będące przedmiotem dyskusji w Niemczech.

Ostatni referat w tej sesji, pt. Ochrona danych osobowych w Kościele $w$ prawie polskim wygłosił ks. prof. Artur Mezglewski (UO). Prelegent dokonał analizy przepisów prawa polskiego, w szczególności skupiając się na ustawie o ochronie danych osobowych z dnia 29 sierpnia $1997 \mathrm{r}$. Swoje wystąpienie zogniskował na zagadnieniach dotyczących przesłanek do legalnego przetwarzania danych osobowych, ograniczeń kompetencji GIODO wobec kościołów i związków wyznaniowych oraz kwestii udostępniania danych osobowych.

Ochrona danych osobowych $w$ świetle prawa kanonicznego to tytuł trzeciej sesji konferencji. Przewodniczyła jej dr Edyta Bielak-Jomaa (GIODO). Pierwszym referatem tej sesji było wystąpienie ks. prof. Mieczysława Różańskiego (UWM) nt. Przetwarzanie danych osobowych w archiwach kościelnych. Dokonując analizy m.in. przepisów Kodeksu Prawa Kanonicznego z 1983 r. prelegent odpowiedział na pytanie o przetwarzanie danych osobowych zawartych w archiwach kościelnych.

Drugim, a zarazem ostatnim referatem tej sesji było przedłożenie wygłoszone przez ks. prof. Zbigniewa Jancewicza (UKSW) pt. Przetwarzanie danych osobowych $w$ kancelariach parafialnych. Prelegent dokonał próby omówienia czynności duszpasterskich dokonywanych w kancelarii parafialnej. Uwzględniając zaś przepisy prawa kanonicznego, wyjaśnił na czym polega przetwarzanie danych osobowych zawartych w księgach bądź w kartotekach parafialnych.

Sesji czwartej, zatytułowanej Aktualne problemy ochrony danych osobowych $w$ Kościele, przewodniczył ks. prof. Piotr Mazurkiewicz (UKSW). Została ona podzielona na dwie części. Pierwszą z nich była 
dyskusja panelowa, w której udział wzięli: ks. dr Tomasz Jakubiak (Papieski Wydział Teologiczny w Warszawie), prof. Małgorzata Jaśkowska (UKSW), dyr. Monika Krasińska (Biuro GIODO) oraz prof. Irena Lipowicz (UKSW). Drugą częścią była dyskusja otwarta w której głos swój zabrali w kolejności: ks. prof. Artur Mezglewski (UO), prof. Małgorzata Jaśkowska (UKSW), ks. prof. Mieczysław Różański (UWM), ks. dr Tomasz Jakubiak (Papieski Wydział Teologiczny w Warszawie) oraz ks. prof. Leszek Adamowicz (przedstawiciel KEP, KUL).

Podsumowania obrad dokonał prof. Zbigniew Cieślak (UKSW). W swoim wystąpieniu zatytułowanym $O$ potrzebie zmian polskiej regulacji prawnej ochrony danych osobowych zwrócił uwagę na bogactwo art. 25 ust. 3 Konstytucji z 1997 r. Ponadto odniósł się do unormowań związanych z ochroną danych osobowych w Kościele w Niemczech i we Włoszech. Na zakończenie Konferencji dr Edyta Bielak-Jomaa (GIODO) podziękowała prelegentom za ich twórcze wystąpienia, a wszystkim za liczny udział.

Ks. mgr lic. Michat Czelny Wydziat Prawa, Prawa Kanonicznego i Administracji Katolicki Uniwersytet Lubelski Jana Pawła II

\section{Ogólnopolskie sympozjum pt. Wolność religijna $i$ wolność sumienia w Polsce, Kraków, 3 marca 2016 r.}

W dniu 3 marca 2016 r. w Krakowie odbyło się ogólnopolskie sympozjum naukowe pt. Wolność religijna $i$ wolność sumienia $w$ Polsce. Sympozjum zostało zorganizowane przez doktorantów Wydziału Prawa Kanonicznego Uniwersytetu Papieskiego Jana Pawła II.

Program sympozjum składał się z dwóch sesji: profesorskiej i studenckiej. Otwarcia dokonał bp dr hab. Grzegorz Ryś, a następnie wprowadzenia dokonał ks. prof. dr hab. Tomasz Rozkrut - Dziekan Wydziału Prawa Kanonicznego UPJPII, który podkreślił aktualność omawianej problematyki w związku ze skomplikowaną sytuacją w Europie, która dotyczy nie tylko pojedynczej osoby, a także rodziny i całego społeczeństwa.

Pierwszej sesji przewodniczył ks. dr Andrzej Sosnowski CR - prodziekan Wydziału Prawa Kanonicznego UPJPII. Pierwszy referat pt. Czy 